\title{
Using the Carbon Budget Model of the Canadian Forest Sector (CBM-CFS3) to examine the impact of harvest and fire on carbon dynamics in selected forest types of the Canadian Boreal shield
}

\author{
by N. Luckai ${ }^{1}$, G.R. Larocque ${ }^{2}$, L. Archambault ${ }^{2,3}$, D. Paré2 ${ }^{2}$ R. Boutin ${ }^{2,3}$ and A. Groot ${ }^{4}$
}

\begin{abstract}
The objective of the study was to assess the responsiveness of the Carbon Budget Model of the Canadian Forest Sector (CBM-CFS3) to management scenarios that included three rotation lengths (50, 100 and 250 years) under harvest and fire disturbances in six forest types (poplar deep soil, black spruce deep soil, jack pine deep and shallow soils, hardwood mixedwood and other conifer lowland). Outputs from five carbon (C) pools were considered: merchantable stemwood (stump height of $30 \mathrm{~cm}$, minimum DBH of $9 \mathrm{~cm}$ and a minimum top diameter of $7 \mathrm{~cm}$ ), deadwood, soil C, total ecosystem $\mathrm{C}$ and cumulative total ecosystem $\mathrm{C}$ emissions. Yield curves strongly affected the predicted size of all five pools. Longer rotation lengths led to larger pools with the relative differences between rotation lengths varying with stand types. Pools associated with poplar were usually the largest while those of jack pine on shallow sites were generally the smallest. When compared to the starting point of the simulations, cumulative total ecosystem $\mathrm{C}$ and $\mathrm{C}$ emissions increased with the 100- and 250-year harvest rotations (HARV100 and HARV250, respectively) and declined with the 50-year harvest rotation (HARV50). Fire disturbances resulted in stable pools of cumulative ecosystem $\mathrm{C}$ and declines in C emissions. CBM-CFS3 provided realistic pool values but the authors suggest further development of the model depiction of ecosystem processes, especially with respect to the treatment of respiration. In general, the authors recommend that forest management planners consider using an integrated approach that links multiple proven and accepted models under appropriate model linking software.
\end{abstract}

Key words: carbon cycling, carbon stocks, landscape level models, growth and yield curves, simulation modelling, boreal forest management scenarios

\section{RÉSUMÉ}

Lobjectif de cette étude a été dévaluer la réactivité du Modèle du bilan de carbone du secteur forestier canadien (MBCSFC3) à des scénarios d’aménagement de perturbations après récolte et feu sous trois durées de rotation (50, 100 et 250 ans) dans six types de forêts (peuplier en sol profond, épinette noire en sol profond, pin gris en sols profond et superficiel, feuillus mélangés et autres conifères en plaine. Les extrants de cinq stocks de carbone (C) ont été considérés: tiges de taille marchande (hauteur à la souche de $30 \mathrm{~cm}$, dhp minimum de $9 \mathrm{~cm}$ et diamètre minimum de $7 \mathrm{~cm}$ au sommet de la tige), bois mort, $\mathrm{C}$ du sol, $\mathrm{C}$ total de lécosystème et émissions cumulatives totales de $\mathrm{C}$ de lécosystème. Les courbes de croissance ont grandement influencé les prédictions des cinq stocks. De plus longues rotations ont résulté en des stocks de C plus élevés, mais les différences relatives entre les durées de rotation ont varié selon les types forestiers. Les stocks associés avec le peuplier ont été les plus élevés, tandis que ceux du pin gris sur sol superficiel ont généralement été les plus petits. Par rapport aux valeurs initiales des simulations, le $\mathrm{C}$ cumulatif total et les émissions de $\mathrm{C}$ ont augmenté après récolte sous les rotations de 100 et 250 ans (HARV100 et HARV250, respectivement), et diminué sous la rotation de 50 ans (HARV50). Les perturbations résultant de feux ont résulté en des stocks stables de $\mathrm{C}$ cumulatif de lécosystème et une diminution des émissions de C. MBC-SFC3 a prédit des valeurs réalistes de $\mathrm{C}$, mais les auteurs suggèrent des développements additionnels dans la description des processus de lécosystème, particulièrement en ce qui concerne le traitement de la respiration. En général, les auteurs recommandent que les aménagistes forestiers considèrent ultiliser une approche intégrée basée sur l'utilisation de plusieurs modèles couramment acceptés, qui ont fait leur preuve, à l'aide de logiciels intégrateurs appropriés.

Mots-clés : cycle du carbone, stocks de carbone, modèles à léchelle du paysage, courbes de croissance et production, simulation, scénarios d’aménagement dans la forêt boréale.

\footnotetext{
${ }^{1}$ Faculty of Natural Resources Management, Lakehead University, 955 Oliver Road, Thunder Bay, Ontario P7B 5E1. Corresponding author. E-mail: nluckai@lakeheadu.ca

${ }^{2}$ Natural Resources Canada, Canadian Forest Service, Laurentian Forestry Centre, 1055 du P.E.P.S. Stn, Ste. Foy, Quebec G1V 4 C7.

${ }^{3}$ Retired

${ }^{4}$ Natural Resources Canada, Canadian Wood Fibre Centre, 1219 Queens St. E., Sault Ste. Marie, Ontario P6A 2E5.
} 


\section{Introduction}

Forest management and its associated activities, such as fire suppression, harvesting, regeneration, and stand tending, influence the terrestrial carbon (C) cycle (Colombo et al. 2005; Hyvönen et al. 2007; Kurz et al. 2008a,b, 2009; TerMikaelian et al. 2008) and have the potential to contribute to reducing atmospheric greenhouse gas emissions (Golden et al. 2011) but there are still many uncertainties about the magnitude of the impacts of different management practices (Jandl et al. 2007). Estimating C fluctuations in managed forests is therefore important but forest managers have limited resources for doing so. In this case study, we used the third version of the Carbon Budget Model of the Canadian Forest Sector (CBM-CFS3) to investigate the effects of harvesting and fire on $\mathrm{C}$ pools in typical forest types found in northwestern Ontario.

Those involved with forest management planning (FMP) are increasingly interested in considering alternatives to or understanding the implications of a particular decision with respect to $\mathrm{C}$. Given the complexity of $\mathrm{C}$ flow in forest systems and its intimate relationship with nutrient cycling, computerbased models can be helpful in predicting the response of primary producers to environmental change. The Canadian Forest Service began development of its Carbon Budget Model (CBM) in the early 1990s; it was designed to predict the impact of forest management activities on $\mathrm{C}$ gains and losses by estimating pools associated with above- and below-ground biomass, dead organic matter (DOM) and soil organic matter (e.g., Kurz et al. 1992, 1996; Price et al. 1997; Kurz and Apps 1999; Banfield et al. 2002; Li et al. 2002; Liu et al. 2002). The version used in this case study, CBM-CFS3, includes regional parameter values and databases allowing the estimation of landscape-level C stocks and C stock changes (Kurz et al. 2002). Although much has been achieved with respect to developing a Canadian $\mathrm{C}$ model, there is a need to test the application of CBM-CFS3 under different management scenarios in various forest types (Kurz et al. 2009), to consider the limitations of the model and to validate model output. The objective of the present study was therefore to examine the extent to which CBM-CFS3 was responsive to management scenarios that included three rotation lengths under harvest and fire disturbances in six forest types found on the Canadian Boreal Shield in northwestern Ontario.

\section{Model Framework and Scenario Development Model framework}

CBM-CFS3 (hereafter referred to as CBM) is a landscapelevel $\mathrm{C}$ budget model capable of retrospective or predictive analysis. The basic framework of the model is shown in Fig. 1. Seven input files are required when using the standard import tool (i.e., data in Microsoft Excel) (Table 1). The model, as available from the CFS website, includes a number of default settings. For example, mean annual temperature and precipitation are assigned based on the administrative region, but users can also provide their own data. Values for biomass and DOM turnover, disturbance intensity, growth and yield, and volume to biomass conversion can be left at the default or changed to suit individual scenarios. Within CBM, all $\mathrm{C}$ is contained in pools as shown in Fig. 1. Biomass pools include foliage, stemwood, other (sapling stemwood, merchantable stem bark, branches, tops and stumps), coarse and fine roots. DOM pools have two defining characteristicsposition (either above- or below-ground) and carbon residency time (ranging from "very fast" to "very slow"). Users can modify the rate of movement between the different pools, including litterfall and decomposition. As disturbances, wildfires and harvests differ in the quantity of $\mathrm{C}$ transferred from biomass (living) pools to DOM pools. The impact of any dis-

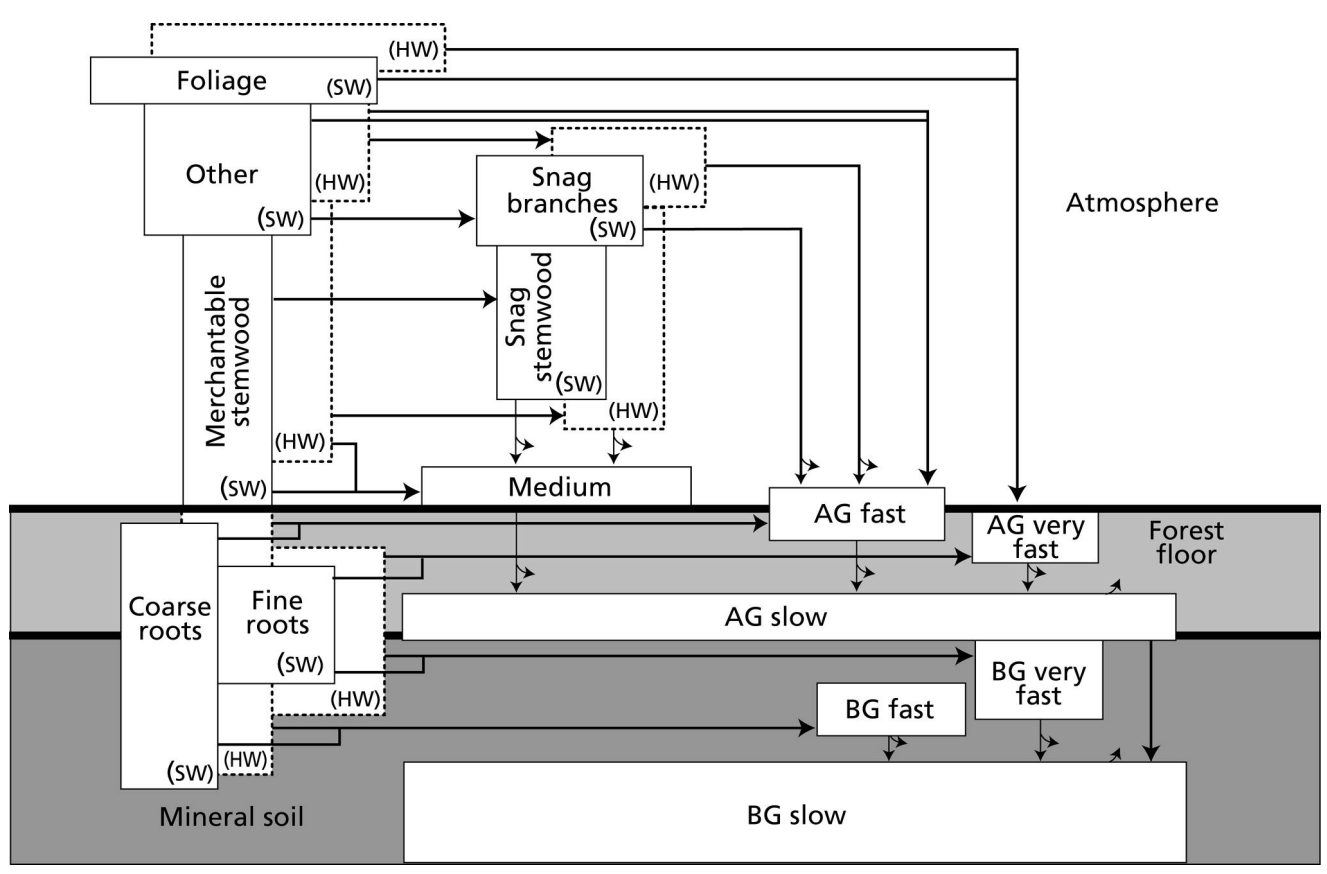

Fig. 1. The carbon pool structure of the CBM-CFS3. "Very fast," "fast," "medium," and "slow" refer to the relative decay rates for the pools. Curved arrows represent transfers of carbon to the atmosphere, and straight arrows represent transfers from one pool to another.SW = softwood, HW = hardwood, AG = aboveground, BG = belowground. (Kull et al. 2007) Source: Canadian Forest Service (Natural Resources Canada), reproduced with permission. 
Table 1. Information required in different input files to run simulations with CBM-CFS (Kull et al. 2007)

\begin{tabular}{ll}
\hline File name & Purpose \\
\hline 1. Age-class & $\begin{array}{l}\text { Although CBM iterates stands through time in annual time steps, data is entered in 5-, 10- or 20-year time } \\
\text { increments. }\end{array}$ \\
2. Disturbance types & $\begin{array}{l}\text { Provides information on all possible disturbance types (e.g., fire or harvest). A disturbance affects a stand or a } \\
\text { proportion of stands and has a direct effect on live and dead carbon pools, the impact of which is that the pro- } \\
\text { portion of biomass and DOM that transfers between the carbon pool, the atmosphere and the forest product } \\
\text { sector is changed. }\end{array}$ \\
$\begin{array}{l}\text { Lists stand characteristics defining the unique attribute(s) of the different stand types and thereby determines } \\
\text { the growth and yield curve to be assigned to a stand. Classifying a stand as being hardwood- or softwood-domi- } \\
\text { nated allows CBM to choose a volume to biomass conversion parameter. }\end{array}$ \\
$\begin{array}{l}\text { An inventory file lists each stand or group of stands along with its classifiers and values; this includes origin (fire } \\
\text { or harvesting), age, size and whether hardwoods or softwoods dominate the stand. }\end{array}$ \\
$\begin{array}{l}\text { Provides information on gross merchantable (m }{ }^{3} \text { ha }{ }^{-1} \text { ) volume for each uniquely identified stand. } \\
\text { 5. Growth and yield }\end{array}$ \\
$\begin{array}{l}\text { Allow for change (species and/or yield) in stand type after a disturbance or management event. } \\
\text { 7. Transition rules }\end{array}$ \\
$\begin{array}{l}\text { Users must provide disturbance information with regard to amount (i.e., area) and identification of eligible } \\
\text { stands (based on classifiers). The impact of disturbances is defined in "disturbance matrices" that define the pro- } \\
\text { portion of each biomass and DOM pool that is transferred (to another C pool, the atmosphere or forest product } \\
\text { sector). Post disturbance dynamics are defined by the new growth and yield curves to which the disturbed area } \\
\text { is allocated. }\end{array}$ \\
\hline
\end{tabular}

Table 2. Descriptions of selected forest units in northwestern Ontario used to simulate effects of different forest management scenarios on carbon accounting. Forest unit names and descriptions are found in OMNR (2004).

\begin{tabular}{|c|c|}
\hline Forest Unit Name & $\begin{array}{l}\text { Species Composition } \\
\text { (based on } \% \text { of Basal area }\left(\mathrm{m}^{2} \mathrm{ha}^{-1}\right) \text { and stocking) }\end{array}$ \\
\hline $\begin{array}{l}\text { HRDMW (Hardwood- } \\
\text { Dominated Mixedwood) }\end{array}$ & $\begin{array}{l}\text { Trembling Aspen + White Birch + Mixed Hardwoods } \\
+ \text { Upland Hardwoods + Lowland Hardwoods } \geq 50 \%\end{array}$ \\
\hline $\begin{array}{l}\text { OCLOW } \\
\text { (Other Conifer Lowland) }\end{array}$ & $\begin{array}{l}(\text { Cedar }+ \text { Larch } \geq 50 \% \text { or Working Group }=\text { Cedar or Working Group }=\text { Larch }) \text { and }(\text { Red Pine }+ \text { White } \\
\text { Pine }+ \text { Jack Pine }+ \text { White spruce }+ \text { White Birch }<10 \%)\end{array}$ \\
\hline $\begin{array}{l}\text { PJDEE } \\
\text { (Jack Pine Deep Soil) }\end{array}$ & $\begin{array}{l}\text { (Jack Pine } \geq 70 \% \text { and Trembling Aspen }+ \text { White Birch } \leq 20 \% \text { ) or (Jack Pine } \geq 50 \% \text { and Trembling Aspen } \\
+ \text { White Birch } \leq 20 \% \text { and AGE } \geq 120 \text { years) or (Jack Pine } \geq 70 \% \text { and Stocking } \geq 0.6 \text { ) }\end{array}$ \\
\hline $\begin{array}{l}\text { PJSHA } \\
\text { (Jack Pine Shallow Soil) }\end{array}$ & Jack Pine $\geq 70 \%$ and Trembling Aspen + White Birch $\leq 20 \%$ \\
\hline $\begin{array}{l}\text { PODEE } \\
\text { (Trembling Aspen Deep Soil) }\end{array}$ & Trembling Aspen $\geq 70 \%$ and Stocking $\geq 0.5$ \\
\hline $\begin{array}{l}\text { SBDEE } \\
\text { (Black Spruce Deep Soil) }\end{array}$ & Black Spruce $\geq 70 \%$ and Trembling Aspen + White Birch $\leq 20 \%$ and Stocking $\geq 0.6$ \\
\hline
\end{tabular}

turbance is defined in a "disturbance matrix" (Kurz et al. 1992) that quantifies the proportion of each pool that is transferred to another $\mathrm{C}$ pool or to the atmosphere with the exception that, after harvesting, all stemwood $\mathrm{C}$ is transferred to the forest products sector. The version of the model that we used did not consider the fate of $\mathrm{C}$ in the forest products sector. For simulation purposes, we used the default disturbance matrices provided with the model for the northwestern Ontario region.

Although CBM uses the term "forest stand" to identify a community of trees uniform in species, composition, age and management type, we have opted to use the term "forest unit" as per the Ontario Ministry of Natural Resources (OMNR 2004) FMP manual. A forest unit is a classification system that aggregates forest stands for management purposes, which will normally have similar species composition, will develop in a similar manner (both naturally and in response to silvicultural treatments), and will be managed under a common silvicultural system. We selected six forest units based on their prevalence in typical managed forests, leading species (hardwood and softwood) and growth patterns in northwestern Ontario (Table 2).

For every forest unit there must be a corresponding growth and yield curve. Within CBM, all above-ground (AG) and below-ground (BG) tree biomass components, that eventually lead to all DOM pools, are estimated from this information (Kull 2007). The present study utilized yield curves based on MOSSY ${ }^{\odot}$, software developed by the OMNR to pro- 
vide yield curves for pure and mixed species stands (Penner et al. 2008). The derived curves represent average stand conditions for all of the stands used to create the curves; there is no differentiation based on individual stand characteristics such as stocking, density or site index (Fig. 2). The curves also illustrate differences in productivity and reflect ecological characteristics of the leading species. For example, shadeintolerant species such as trembling aspen (Populus tremuloides Michx.; PODEE) and jack pine (Pinus banksiana Lamb.; PJDEE, PJSHA) colonize disturbed sites, grow rapidly and reach maximum volumes around 100 years (Perala 1990, Rudolf and Laidly 1990). More tolerant species such as black spruce (Picea mariana [Mill.] BSP; SBDEE) and other conifers (OCLOW), tend to establish slowly but gain volume over a longer period of time.

Curves were arbitrarily extended to 250 years. For black spruce (SBDEE) and other conifer lowland (OCLOW), this resulted in continual, gradual increases in volume; curves for the remaining forest units (PJDEE, PODEE, PJSHA, HRDMW) showed only a small increase after 100 years. That the gross merchantable curves extend to 250 years may appear unrealistic, particularly for trembling aspen and jack pine. Both species, considered as short-lived (Perala 1990, Rudolf and Laidly 1990), reach a maximum volume well before this age (Fig. 2). In addition, there is little evidence in the literature that such stands can maintain a relatively stable volume as mortality rate increases with stand age. Also, it could be argued that a proportion of the stands disturbed should have succeeded to other forest units. Nonetheless, it was decided to keep these curves and to assume continuity of forest unit type. As the focus of the study was to evaluate the sensitivity of CBM to predict carbon pools and flows for different rotation ages and management strategies, it was deemed necessary to hold these variables constant.

\section{Management scenarios}

To capture a range of management scenarios and their effect on major forest carbon pools, we developed four scenarios that used age-class distribution, disturbance return interval and disturbance type as the key variants (Fig. 3). Age-class distribution is a function of various natural and anthropogenic processes such as harvesting, fire, windthrow and succession. In a highly managed setting where consistent quantities of wood are required (i.e., for mill consumption), equal areas and/or amounts of wood would be harvested each year. Commonly referred to as a fully regulated forest, this distribution was selected because it is a classic model of forest regulation (see Diaz-Balteiro et al. 2009). The HARV50, HARV100 and HARV250 represent short-, mid- and longrotation harvest scenarios, respectively. The short and long harvest scenarios may provide some insight into pressures to adopt more intensive management to increase productivity and more extensive management to increase the number of stands in a mature condition, respectively.

In a forest subjected to regular fire disturbances, van Wagner (1978) proposed that a negative exponential age-class distribution would develop. The FIRE100 scenario utilized the negative exponential distribution with an average disturbance return interval of 100 years. The total area of each forest unit was fit to a negative exponential pattern and then adjusted such that the area beyond the limits of the available

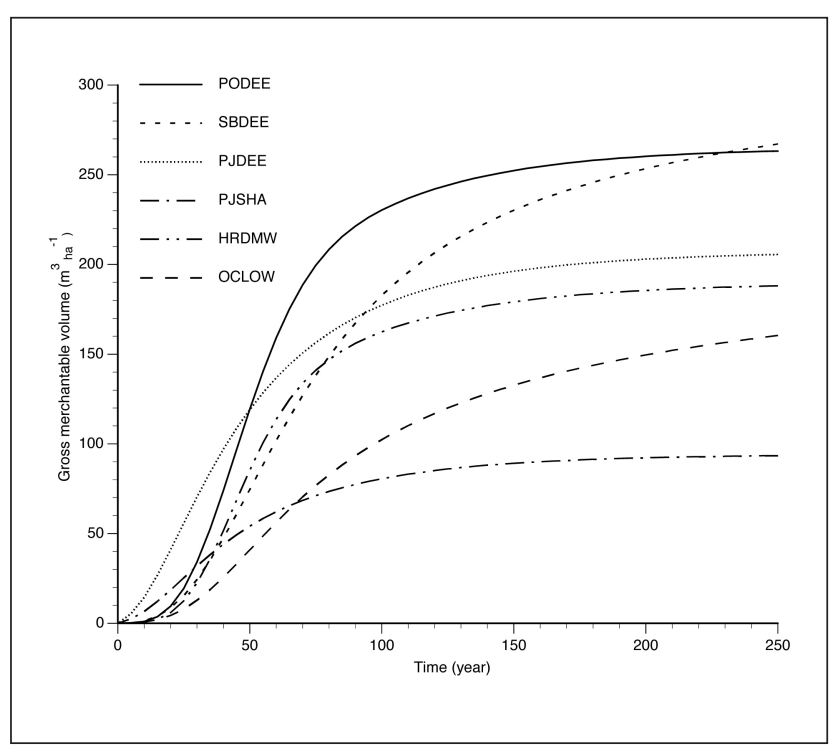

Fig. 2. Growth curves for the six forest units used in the simulation of carbon budget with CBM-CFS3 in selected forest units of the Canadian Boreal shield.

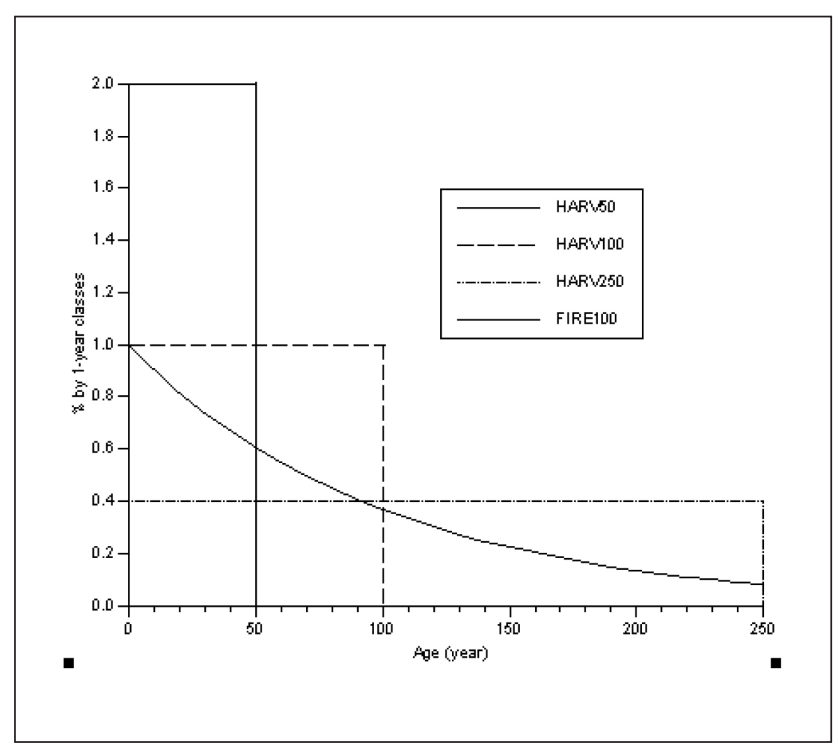

Fig. 3. Schematic illustration to compare three scenarios of fully regulated forests occupying the same area with different harvest rotation ages (HARV50, HARV100 and HARV250) with a scenario of a negative exponential distribution based on an average fire frequency (return interval) of one every 100 years (FIRE100).

yield curves was incorporated proportionally into each year of the inventory. Implementation of this scenario involved burning a portion of each age-class every year for 250 years as well as the entire area of stands in their final year. When any forest area was burned, the age-class of that area was reset to zero. All scenarios used the same yield curves according to forest unit.

\section{Selection of model output variables}

CBM provides more than 100 output variables under the major categories of Stocks $(\mathrm{t})$, Stock Changes $\left(\mathrm{t} \mathrm{yr}^{-1}\right)$, Ecosys- 
tem Indicators $\left({\mathrm{t} \mathrm{yr}^{-1}}^{-1}\right.$, Ecosystem Transfers $\left(\mathrm{t} \mathrm{yr}^{-1}\right)$, Emissions $\left(\mathrm{t} \mathrm{yr}^{-1}\right)$, Disturbed Area

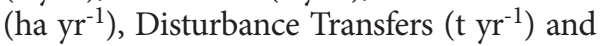
Age Classes. We considered many output variables but present output from five: merchantable stemwood (stump height of 30 $\mathrm{cm}$, minimum DBH of $9 \mathrm{~cm}$ and a minimum top diameter of $7 \mathrm{~cm}$ ), deadwood, soil $\mathrm{C}$, total ecosystem $\mathrm{C}$ and cumulative total ecosystem $\mathrm{C}$ emissions. In this case study, model output is provided at the landscape level; in other words all stands that make up the Forest Unit are included in the unit area average. At any year end, the output is therefore "net" and reflects changes in each Forest Unit at all year levels. Subsequently, it is not possible to trace the pattern attributable to any one stand (or to answer questions such as, do young stands operate differently than middle-aged or older stands?). We therefore chose output from the $250^{\text {th }}$ year of each scenario for all comparisons except percent change in total ecosystem $\mathrm{C}$ and $\mathrm{C}$ emissions.

\section{Results of the Scenarios}

Merchantable stemwood C was highest for all forest types in the longest rotation scenario, HARV250, and lowest in the shortest one, HARV50 (Fig. 4). Amounts for HARV100 and FIRE100 were very similar, falling between the other two scenarios. Absolute values were the lowest for the shallow soil jack pine (PJSHA) and other lowland conifer (OCLOW) forest types, both of which have less productive growth curves (Fig. 2). The interaction of time and yield curve is demonstrated in results for SBDEE, PODEE and PJDEE. At year 100, the volume of PODEE (approximately $240 \mathrm{~m}^{-3} \mathrm{ha}^{-1}$ ) exceeded that of both SBDEE and PJDEE (approximately $175 \mathrm{~m}^{-3} \mathrm{ha}^{-1}$ ). Total merchantable stemwood $\mathrm{C}$ for both the HARV100 and FIRE100 scenarios reflects this hierarchy (as do the values for HRDMW, OCLOW and PJSHA). However,

the link to yield curves was not as clear with either short- or long-rotation harvest scenarios. At 50 years, PODEE and PJDEE curves crossed at approximately $120 \mathrm{~m}^{3} \mathrm{ha}^{-1}$ with SBDEE at just over half that amount $\left(70 \mathrm{~m}^{3} \mathrm{ha}^{-1}\right)$. By comparison, stemwood $\mathrm{C}$ mass for HARV50 increased from SBDEE $\left(7 \mathrm{t} \mathrm{ha}^{-1}\right)$, to PODEE $\left(11 \mathrm{tha}^{-1}\right)$ and to PJDEE $\left(14.7 \mathrm{tha}^{-1}\right)$. At 250 years, the yield curves for SBDEE and PODEE converged, exceeding that of PJDEE by approximately $20 \%$. Stemwood C for the HARV250 scenarios for SBDEE and PJDEE were very similar (30.9 tha-1 and $30 \mathrm{t} \mathrm{ha}^{-1}$, respectively) while that of PODEE was higher at $34 \mathrm{t} \mathrm{ha}^{-1}$. For comparison purposes, 30 t ha ${ }^{-1}$ of $\mathrm{C}$ correspond to approximately $120 \mathrm{~m}^{3} \mathrm{ha}^{-1}$ of wood.

Deadwood C includes material in fast (input from branches, tops, stumps and sub-merchantable trees) AG and BG DOM, medium DOM (merchantable stemwood and/or stem snags), softwood and hardwood stem and branch snag pools. The proportion of $\mathrm{C}$ transferred into the deadwood pools was based on the default parameters provided in CBMCFS3. For each forest unit, the amount of deadwood was greatest under the FIRE100 scenario and increased with average age under the harvest scenarios (Fig. 5). Within each scenario, PJSHA exhibited the lowest deadwood values and PODEE, the highest. The values of both forest units differed by a two-fold factor. This pattern coincided with the yield curves (Fig. 2) and merchantable stemwood predictions (Fig. 4).

Soil C accounts for C in Very Fast BG (coarse and fine root biomass) and Slow BG pools (input from Very Fast, Fast and Medium BG pools). Overall, soil C was greatest in the hardwoods regardless of scenario (Fig. 6). The pattern was the same as that for deadwood $\mathrm{C}$, although the relative differ- 


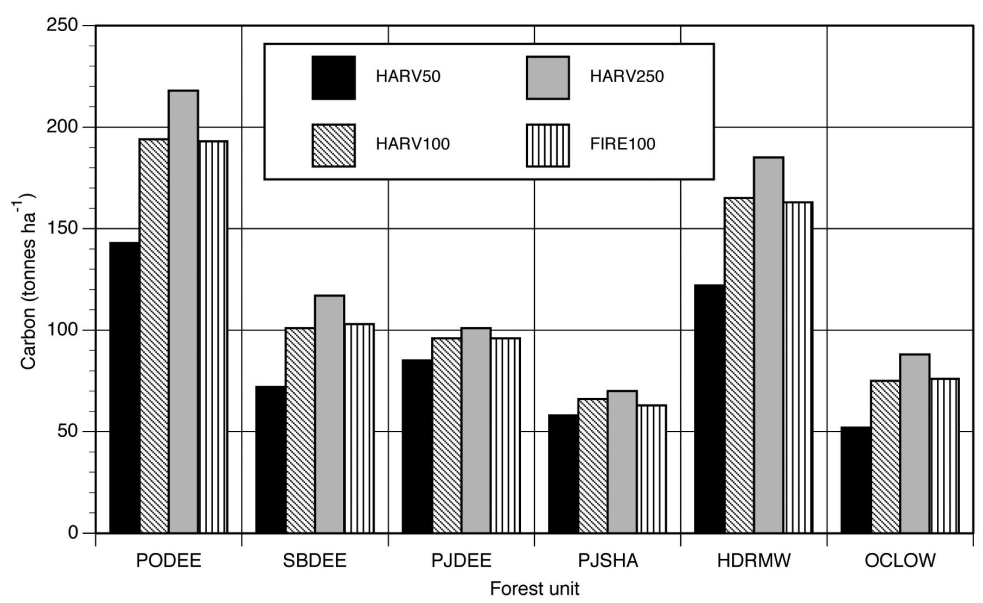

Fig. 6. Soil carbon content per unit area predicted at the end of a 250 -year simulation period using scenarios of harvesting with rotations of 50,100 and 250 years (HARV50, HARV100, HARV250) and of a fire frequency of 100 years (FIRE100).

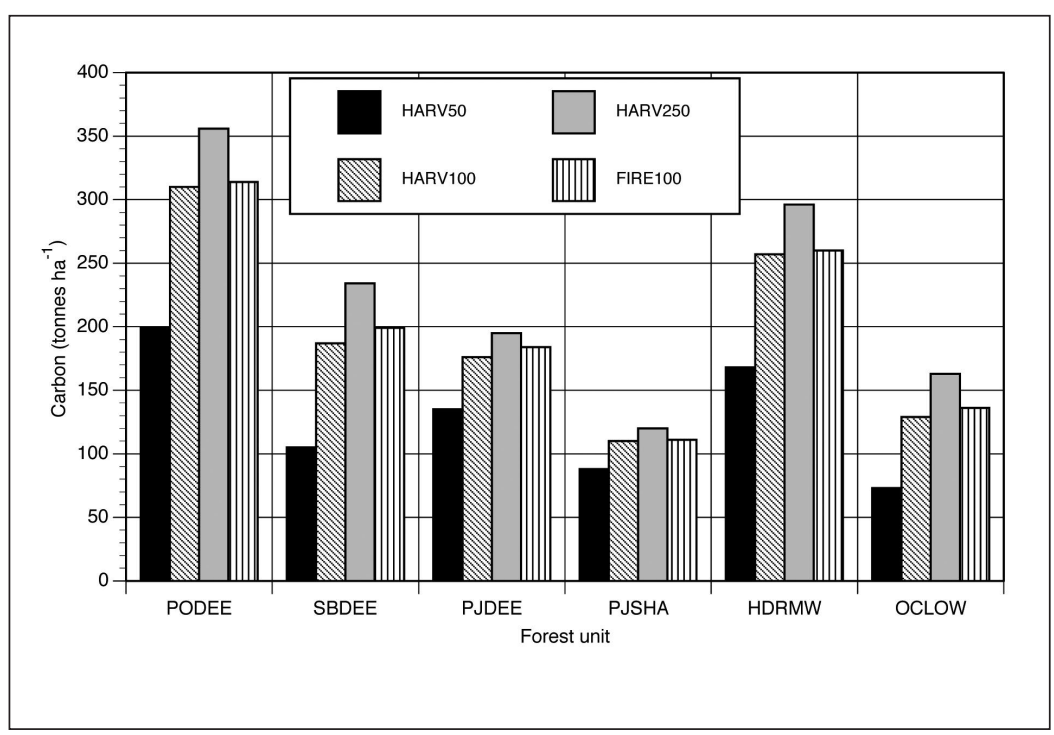

Fig. 7. Total Ecosystem Carbon Content predicted at the end of a 250 -year simulation period using scenarios of harvesting with rotations of 50,100 and 250 years (HARV50, HARV100, HARV250) and of a fire frequency of 100 years (FIRE100). foliage, bark, saplings, branches, tops and stumps), litter and DOM pools. The pattern of total ecosystem $\mathrm{C}$ was very similar to that of soil C (Fig. 7). This is not surprising as soil $\mathrm{C}$ is the largest single component. Hardwood forest units sequestered the largest amounts of $\mathrm{C}$ regardless of scenario. HARV250 and HARV50 scenarios always resulted in the largest and smallest $C$ values, respectively, for each forest unit while there was little difference between the total amounts predicted for FIRE100 and HARV100. For comparison, Shaw et al. (2005) reported mean total ecosystem C amounts ranging from $200 \mathrm{t} \mathrm{ha}^{-1}$ to $300 \mathrm{t}$ $\mathrm{ha}^{-1}$ for the Western and Eastern Boreal Shield terrestrial ecozones, respectively.

Fig. 8 illustrates the percent change in cumulative total ecosystem C over 250 years for each of the forest units and scenarios. Change is relative to the amount of $\mathrm{C}$ present at the time of implementing the scenario (year 0); initial amounts are determined by the MAKELIST portion of the model. All forest units were predicted to lose $\mathrm{C}$ over time under the HARV50 scenario. Losses ranged from approximately $7 \%$ for HRDMW to nearly $19 \%$ for SBDEE. By comparison, all forest units were predicted to gain $\mathrm{C}$ over time under HARV100 and HARV250 scenarios. The smallest gains were obtained for PJDEE and HRDMW (between 2\% and 5\%) and the largest gains (between 12\% and 16\%) for OCLOW. There was little change in the FIRE100 scenario over the course of 250 years. This reflects the similarity between the outcomes of the MAKELIST section of the model (which uses a fire return interval of 75 years) and the FIRE100 scenario imposed subsequently.

Total emissions include $\mathrm{C}\left(\mathrm{CO}, \mathrm{CO}_{2}\right.$, and $\mathrm{CH}_{4}$ ) from all ecosystem components (DOM and biomass) (Kull et al. 2007). Cumulative values are the sum of all C emissions over the 250 years of the scenarios (Fig. 9). In general, total $C$ emissions values are three to four times those predicted for total ences were much greater (PODEE, HDRMW, SBDEE, PJDEE, OCLOW and PJSHA in descending order). For example, the sum of all PODEE deadwood exceeded that of SBDEE by approximately $20 \%$, while the same comparison for soil C yielded a difference of nearly $50 \%$ (750 $\mathrm{t} \mathrm{ha}^{-1}$ vs. 390 $\left.\mathrm{t} \mathrm{ha}^{-1}\right)$. Soil $\mathrm{C}$ was greatest in the longest harvest scenario and least in the shortest harvest scenario; soil $\mathrm{C}$ amounts generated by the mid-length scenarios (HARV100 and FIRE100) were nearly identical, falling between the short and long rotation scenarios. For comparison purposes, Siltanen et al. (1997) report mean mineral soil C for the Boreal East ecoclimatic province (which includes northwestern Ontario) of 7.3 $( \pm 0.3) \mathrm{kg} \mathrm{m}^{-2}$ or $73( \pm 3) \mathrm{t} \mathrm{ha}^{-1}$.

Total ecosystem $\mathrm{C}$ includes carbon in all biomass (fine and coarse roots, merchantable and sub-merchantable stemwood, ecosystem carbon at year 250 (Fig. 7). C emissions (proportion of released atmospheric $\mathrm{C}$ when there is a $\mathrm{C}$ transfer from one pool to another) were calculated using default values. Predicted emissions were always lowest for the HARV50 scenario, varying from $256 \mathrm{t} \mathrm{ha}^{-1}$ (OCLOW) to $717 \mathrm{t} \mathrm{ha}^{-1}$ (PODEE). Highest emissions were found in the HARV250 and FIRE100 scenarios and ranged from $391 \mathrm{t} \mathrm{ha}^{-1}$ (PJSHA) to $1311 \mathrm{t} \mathrm{ha}^{-1}$ (PODEE).

Fig. 10 illustrates the percent change in cumulative total C emissions predicted over the 250 period. Similar to Fig. 8, there are declines from the values created in MAKELIST in the HARV50 scenario and increases in HARV100 and HARV250. FIRE100 predictions include small declines (with PJSHA only slightly below 0 and the other five forest units varying from $-3 \%$ to $-4 \%$ after 100 years). 

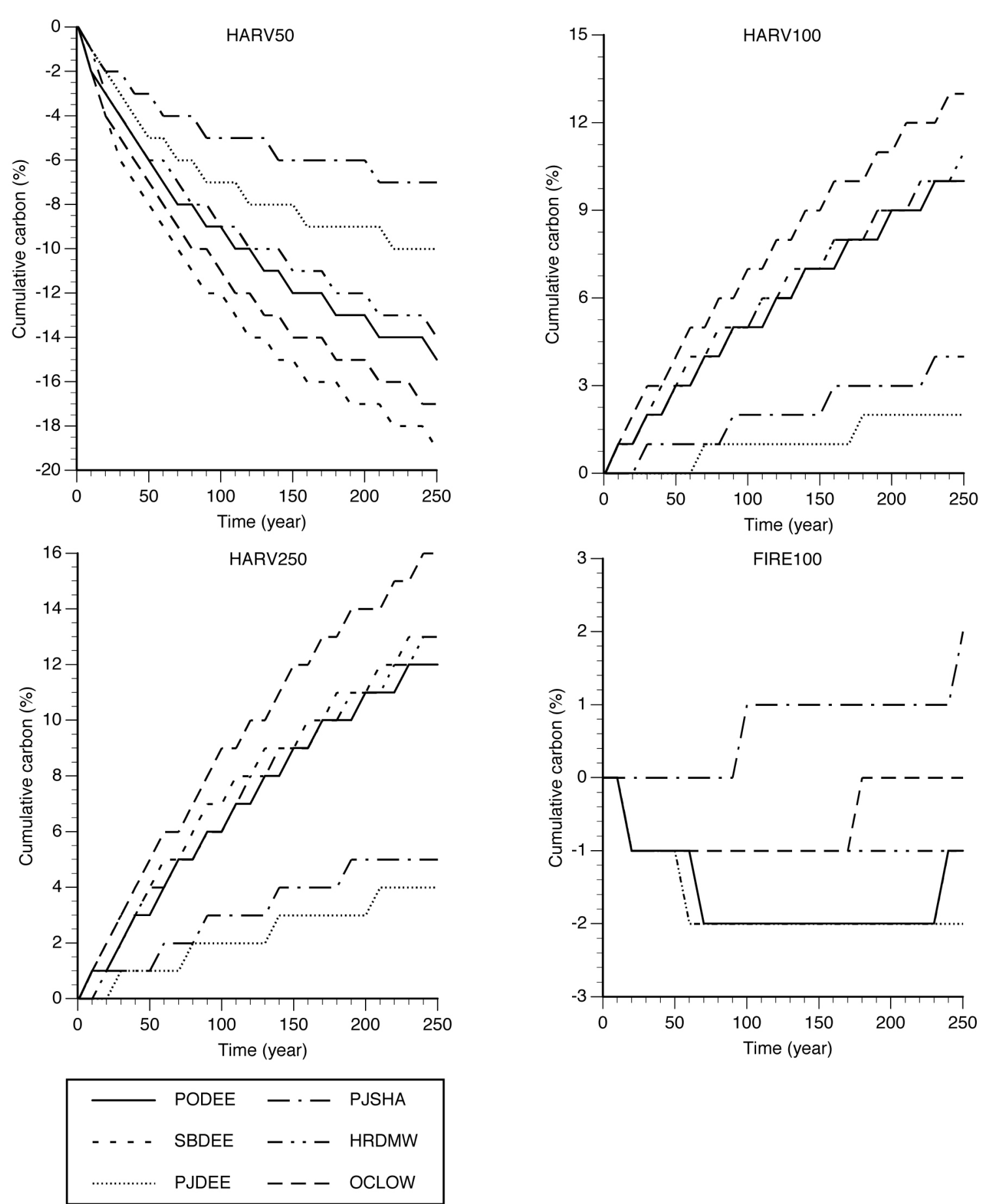

Fig. 8. Percent changes in cumulative total ecosystem carbon predicted during a 250 -year simulation period using scenarios of harvesting with rotations of 50, 100 and 250 years (HARV50, HARV100, HARV250) and a fire frequency of 100 years (FIRE100).

\section{Discussion}

Given the impact of the growth curves on all pools and flows and the assumptions made in extending those curves to 250 years (Fig. 2), a subsequent modeling study should include both potential successional pathways and modified volume curves especially when simulating long management periods. Such information could be obtained from long-term datasets (such as the OMNR's Permanent Sample Plot program) or from predictions based on gap- and/or processbased models that could account for changes in species composition over time. As gap models simulate species replacement, they can be used to predict changes in species composition over long periods of time (see Larocque et al. 2006). Process-based models can be programmed to include 


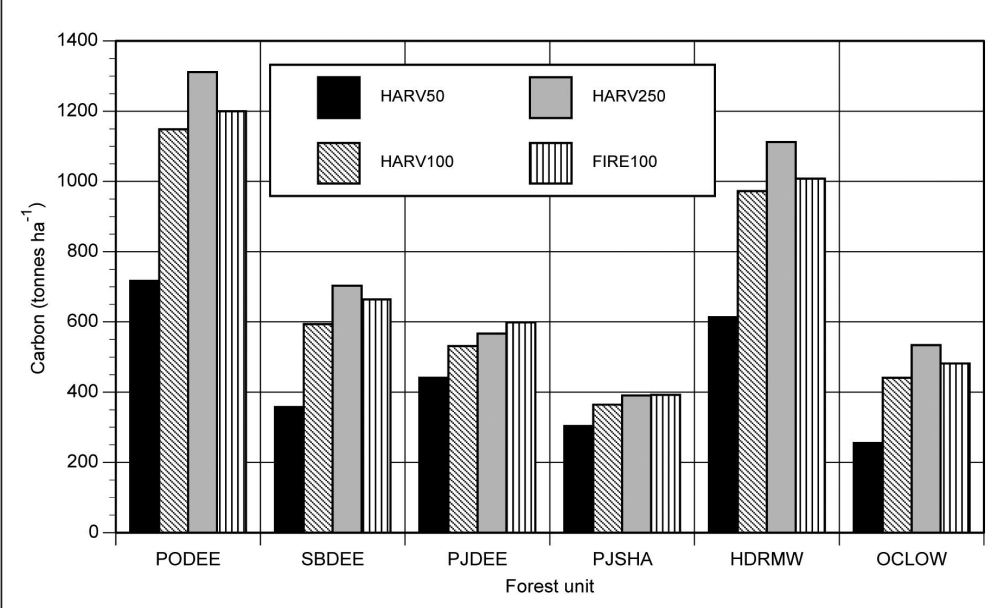

Fig. 9. Cumulative total ecosystem $C$ emission predicted at the end of a 250 -year simulation period using scenarios of harvesting with rotations of 50, 100 and 250 years (HARV50, HARV100, HARV250) and of a fire frequency of 100 years (FIRE100).

effects of silviculture and/or climate change in growth predictions. Several authors have highlighted the importance of stand structure (e.g., even- or uneven-aged, Carey et al. 2001) and successional stage on $C$ cycling at the landscape or country level (Kurz et al. 1998, Schulze et al. 2000, Law et al. 2000, Bottcher et al. 2008).

Per-hectare amounts of merchantable stemwood C in the different forest units at the end of the 250 year simulation period were closely aligned with the merchantable volume curves (Fig. 2 and Fig. 4). Generally speaking, the lowest amounts were found in forest units with the least productive curves (e.g., PJSHA and OCLOW) and the highest amounts in forest units with the most productive curves (e.g., PODEE and SBDEE). Relative rankings for stemwood $\mathrm{C}$ did change with rotation length in agreement with the relative ranking of the curves. For example, under the HARV50 and HARV250 scenarios, PJDEE had the first- and third-largest average volume per hectare values and SBDEE had the fifth- and firstlargest average volume per-hectare values, respectively. In both cases these rankings reflect those of the respective yield curves at those times. This change in ranking (and volume) over time reinforces the importance of using the most accurate yield curves available, particularly for the conversion from volume to $\mathrm{C}$ biomass. Species-specific conversion factors of merchantable volume to above- and below-ground C biomass components are used (Boudewyn et al. 2007). As the conversion factors have a downstream effect in the amount of $\mathrm{C}$ material available to move into DOM pools through litterfall and mortality, pronounced inaccuracies in the yield curves may deepen differences among forest types. Although the model source code is not accessible to users, we understand from the documentation provided that the process to estimate $\mathrm{C}$ biomass begins with a species-specific translation of merchantable volume to above- and below-ground components in terms of dry matter biomass (Boudewyn et al. 2007), followed by conversion to $\mathrm{C}$ ( $0.5 \mathrm{~g} \mathrm{C} / \mathrm{g}$ dry matter) and application of litterfall and mortality rates. Merchantable stemwood proportions are derived using general hardwood and softwood taper equations (Alemdag 1982, 1988). Stemwood volumes predicted by CBM in this case study are reasonable.
Species-specific characteristics are captured through yield curves, $\mathrm{C}$ allocation patterns and taper curve information. This initial allocation pattern subsequently affects the amount of material available to move into DOM pools through litterfall and mortality.

For deadwood C, the pattern also seems to be related to the merchantable volume curves as modified by a) species-specific (i.e., hardwood $v s$. softwood) differences in mortality and litterfall rates and b) disturbancespecific modifiers. While mortality and litterfall are annual events, disturbance occurs only once in each rotation. Disturbance impacts in CBM are defined using a matrix that describes the proportion of $\mathrm{C}$ transferred between pools (e.g., from Coarse Roots to BG fast DOM), as fluxes to the atmosphere (e.g., increased respiration under insect attack, Kurz et al. 2009) and as transfers to the forest products sector. We used the default matrices associated with clearcut logging (without slash burning) and wildfire. In CBM, harvested stemwood leaves the ecosystem, so the model reports it as a flux to the forest products sector. Under wildfire, the proportion of each pool consumed and the amount of $\mathrm{C}$ emitted to the atmosphere differs (e.g., see Table 5 in Kurz et al. 2009). For example, $C$ in merchantable stemwood, coarse roots, stem and branch snags and BG DOM pools is neither consumed nor emitted. In contrast, virtually all $\mathrm{C}$ in foliage and AG Very Fast DOM (i.e., surface litter) is consumed and emitted as gas ( $90 \%$ is reported as $\mathrm{CO}_{2}, 9 \%$ as $\mathrm{CO}$ and $1 \%$ as $\mathrm{CH}_{4}$ ). Default values for the amount consumed and/or emitted for other pools vary based on species and ecozone. Given that harvested stemwood C is transferred out of the system while burned stemwood $\mathrm{C}$ remains explains some of the differences in amounts assigned to the FIRE100 and the three HARV pools. That the differences are not large, however, may reflect amounts of non-merchantable AG wood and foliage remaining behind after the two disturbances. BG pools and snags are treated similarly regardless of disturbance type.

There is a lack of differences in medium- versus long-rotation harvest scenarios for PODEE, PJDEE, PJSHA and HDRMW. We suggest that this is a direct outcome of the yield curves which flatten out after 100 years. Further support for this statement comes from the observation that deadwood C pools under the longer rotation are larger for both SBDEE and OCLOW, forest types with gradually increasing yield curves. For example, the deadwood pool in PJSHA after 50 years equalled or exceeded those in longer harvest rotations while that of SBDEE at 50 years was roughly half that of SBDEE under 100 - or 250-year rotations. Given that we would expect higher mortality rates as stands age, the relatively low values for deadwood $\mathrm{C}$ under longer harvest scenarios, especially HARV250, are puzzling. However, it must be remembered that CBM utilizes yield curves to determine $\mathrm{C}$ inputs and our yield curves do not identify reductions in stand productivity with age. The size of the deadwood C pool is also affected by transfers out (to soil DOM pools and respiration); if applied, higher decay rates could balance or exceed input rates. This idea is expanded upon in the section under C emissions. 

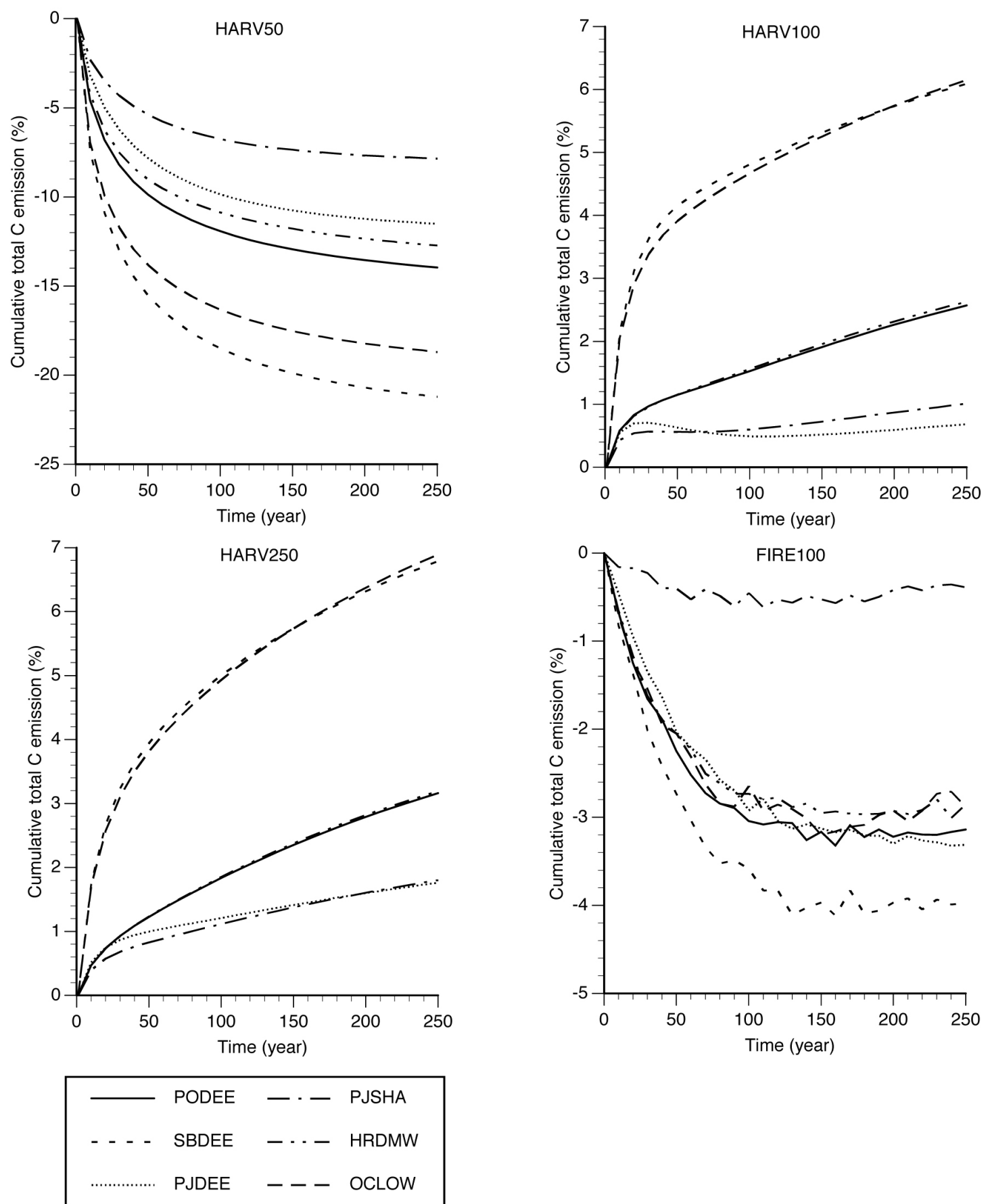

Fig. 10. Percent change in cumulative total $C$ emission predicted during a 250 -year simulation period using scenarios of harvesting with rotations of 50,100 and 250 years and a fire frequency of 100 years.

Differences in soil C pools between forest units were substantial but generally followed the same pattern as that of deadwood C. In particular, both hardwood forest units (PODEE and HRDMW) had much more soil $\mathrm{C}$ than did the conifer units. This pattern may be partly explained by differences in the annual proportion of material that is transferred into litter. CBM-CFS3 default parameters for transfer of stemwood, branches and coarse roots are $0.6 \%, 4 \%$ and $2 \%$, respectively, for all species, while proportions for conifer and hardwood foliage are 10\% and 95\%, respectively (Kurz and Apps 1999). Since decay rates are not adjusted for species, forest units with similar amounts of biomass in the living foliage will therefore exhibit quite different amounts of $\mathrm{C}$ moving through the DOM pools. Differences among forest units continued to be aligned with volume production (Fig. 2) with the greatest soil $\mathrm{C}$ values obtained in PODEE, and the lowest in OCLOW and PJSHA.

How does one determine if differences between the sce- 
narios within each forest unit were or were not relatively important? Three outcomes might be expected. First, that the total amount of soil $\mathrm{C}$ declines, second that it remains constant and third, that it increases. According to Yanai et al. (2003), traditional thinking, based on the work of Covington (1981), suggests that there should be large differences between forests under short and long rotations. Covington's study, based on only one site, resulted in a widely disseminated model showing decreasing forest floor organic matter in the 20 years following harvesting followed by a gradual recovery until about age 50. Repeated short rotations would, under this scenario, result in declining soil C stocks. However, other authors concluded that there is little evidence that harvesting with immediate reforestation significantly affects soil carbon content (e.g., Heath et al. 2002, Lee et al. 2002, Martin et al. 2005, Ter-Mikaelian et al. 2008). Finally, Liski et al. (2002) suggested that an increase in soil C with shortened rotations could be expected because shorter periods between tree harvesting operations tend to increase foliage and branch litterfall from standing trees. In some cases, harvest residues actually increase in relatively young stands because there are fewer stems of merchantable dimensions. In fact, the effects of harvesting on litter decomposition and $\mathrm{C}$ and nutrient transfer to soil $\mathrm{C}$ pools remain controversial. Yanai et al. (2003) concluded that relying too much on Covington's curve to estimate $\mathrm{C}$ transfer to the atmosphere may contribute to overestimating the effect of forest harvesting on the global C budget. CBM-CFS3 results appear to support the idea that shorter rotations do lead to less soil $\mathrm{C}$. However, as is the case with any modelling study, the validity of predictions can only be ascertained when compared to observations from real systems.

Because differences in soil C may be related to climate and litter quality (Meentemeyer 1978, Moorhead et al. 1999), successional stage (Huges and Fahey 1994), soil properties, including texture and parent material, microclimate and soil mixing (Yanai et al. 2003), spatial variation may be quite important. However, CBM was not designed to capture this level of variability. Additional work may be required in order to determine if spatial variation is significant enough to be explicitly considered in models of this type.

With respect to total $\mathrm{C}$ emissions over the length of the simulation, differences between HARV100, HARV250 and FIRE100 scenarios are minimal. Emissions associated with HARV50 are consistently lower (Fig. 9). One could argue that these are the only results that matter in the long run-what is the cumulative impact of management activities on the $\mathrm{C}$ balance of the forest sector? Although obviously of interest to both readers and planners, these results must be interpreted within the context of the CBM model environment. Readers familiar with ecosystem dynamics might expect that total emissions would include both autotrophic (i.e., producer) and heterotrophic (i.e., consumer) respiration along with nonbiological emissions such as fire. As we have seen, CBM does account for emissions associated with fire; however, it does not routinely consider autotrophic respiration. Kurz et al. (2009) explain,

"Chapin et al. (2006) define net ecosystem productivity (NEP) as gross primary productivity (GPP) minus total ecosystem respiration (ER). CBM-CFS3 estimates net ecosystem productivity (NEP) as NPP minus heterotrophic respiration $(\mathrm{Rh})$, where $\mathrm{Rh}$ is the sum of all
DOM pool decomposition losses to the atmosphere.

Neither GPP nor ER is estimated by CBM-CFS3."

Total C emissions are calculated as follows. First, $\mathrm{C}$ is moved from biomass to specific DOM pools based on turnover rates. These range from $95 \% \mathrm{C} \mathrm{yr}^{-1}$ for hardwood foliage, to $64.1 \%$ for fine roots to $0.5 \%$ for merchantable stemwood. Second, C in DOM pools is subject to an applied decay rate, $a_{k}$. The applied decay rate is determined using a base decay rate $\left(\mathrm{BDR}_{\mathrm{k}}\right)$ modified by temperature (TempMod) and stand openness (StandMod). BDRs range from $0.355 \mathrm{yr}^{-1}$ for AG Very Fast to $0.0033 \mathrm{yr}^{-1}$ for BG Slow. Temperature effects are incorporated through the use of $Q_{10}$ values (e.g., 1 for $B G$ Slow, 2 for snag, medium and fast pools and 2.65 for AG Very Fast and Slow pools) and a reference temperature of $10^{\circ} \mathrm{C}$. For example, increasing the temperature to $15^{\circ} \mathrm{C}$ would result in the BDR for snag stems and branches increasing by 1.5 times. StandMod simulates enhanced decomposition that can occur when a canopy is opened. It utilizes an open canopy decay multiplier (MaxDecayMult) and the ratio of existing biomass to maximum biomass (Kurz and Apps 1999). However, given that the MaxDecayMult default value in CBM-CFS3 is set at 1 (Kurz et al. 2009), no change is effected. Third, emissions associated with decomposition of DOM pools are identified as the proportion of decay $\mathrm{C}$ released to the atmosphere $\left(\mathrm{P}_{\mathrm{atm}}\right)$. CBM uses three default values-100\% for AG and BG Slow pool transfers, $83 \%$ for snag stems and branches, medium, AG Fast and BG Fast and Very Fast pool transfers, and $81.5 \%$ for AG Very Fast pool transfers. Disturbance impacts, as discussed earlier, can affect the proportion of $\mathrm{C}$ transferred directly to the atmosphere; however, the main effect is by influencing the amount of material moved into the DOM pools. We compared output for Total Emissions and DOM emissions (data not shown) and found that the former was only slightly higher than the latter; the majority of ecosystem emissions in our scenarios therefore arise from DOM pool decomposition. Given that DOM pools are found primarily in the forest floor and soil organic matter, our validation efforts have therefore focussed on reported measures of soil respiration rather than ecosystem respiration.

$\mathrm{CO}_{2}$ emissions from the soil can be grossly divided into those associated with roots and those associated with activity of microorganisms (Uchida et al. 1998). Unfortunately, separating the measurement of these two sources is very difficult (Hanson et al. 2000) so many studies simply report soil respiration without differentiating the source. Estimates of the proportions of these two sources differ substantially. For example, Hanson et al. (2000) reviewed 37 forest studies and found that root respiration contributed, on average, $48.6 \%$ to total respiration but amounts reported in the studies ranged from $<10 \%$ to $>90 \%$. We will use $48.6 \%$ as our estimate of the root contribution, where necessary, but recognize that many factors (e.g., season, soil temperature, tree physiology, etc.) affect the site specific proportion. A comparison of CBM and reported soil respiration values for typical boreal stand types (Table 3) indicates that the differences are small but the numbers remain realistic. However, the importance of these pools is sufficient to warrant further investigation as to whether CBM consistently underestimates respiration costs.

The increase in the cumulative proportion of $\mathrm{CO}_{2}$ emissions in HARV100 and HARV250 may be explained in part by the changes in tree morphology with increase in size. According to Gower et al. (1996) and Ryan et al. (1997), the 


\begin{tabular}{|c|c|c|c|c|}
\hline \multirow[b]{2}{*}{ Reference } & \multirow[b]{2}{*}{ Species } & \multicolumn{3}{|c|}{ Total Soil Respiration ( $\left.\mathrm{t} \mathrm{Cha}^{-1} \mathrm{yr}^{-1}\right)$} \\
\hline & & $\begin{array}{l}\text { Reported } \\
\text { value }\end{array}$ & $\begin{array}{c}\text { Scenario, } \\
\text { CBM output } \\
\text { (annual average) }\end{array}$ & $\begin{array}{c}\text { Ratio } \\
\text { (CBM value to } \\
\text { reported value) }\end{array}$ \\
\hline Russel and Voroney 1998 & Populus tremuloides & 8.1 & $\begin{array}{l}\text { PODEE } \\
4.8\end{array}$ & 0.59 \\
\hline Gaumont-Guay et al. 2009 & Populus tremuloides & 8.3 & - & 0.58 \\
\hline Tupek et al. 2008 & Spruce-dominated & $4.5-7.7^{\mathrm{a}}$ & - & $0.59-0.34$ \\
\hline Vogel et al. 2005 & $\begin{array}{l}\text { Picea mariana } \\
\text { Various Refs. }\end{array}$ & $\begin{array}{c}3.7 \\
3.9 \text { (mean of } 18 \text { studies) }\end{array}$ & $\begin{array}{l}\text { SBDEE } \\
2.7\end{array}$ & $\begin{array}{l}0.73 \\
0.68\end{array}$ \\
\hline Buchmann 2000 & Picea abies & 7.1 & - & 0.37 \\
\hline Tupek et al. 2008 & Pine-dominated & $4.2-6.5^{\mathrm{a}}$ & - & $0.57-0.37$ \\
\hline Howard et al. 2004 & Pinus banksiana & $3.7^{\mathrm{b}}$ & $\begin{array}{l}\text { PJDEE } \\
2.4\end{array}$ & 0.65 \\
\hline Streigl and Wickland 1998 & Pinus banksiana & 2.7 & - & 0.89 \\
\hline McCaughey et al. 2006 & Mixedwood & $9.2^{c}$ & $\begin{array}{l}\text { HRDMW } \\
\quad 4.0\end{array}$ & 0.65 \\
\hline Lavigne et al. 2003 & Abies balsamea & $\begin{array}{c}6.7-11.9 \\
\text { (cool to warm sites) }\end{array}$ & $\begin{array}{c}\text { OCLOW } \\
1.9\end{array}$ & $0.29-0.16$ \\
\hline
\end{tabular}

a original values reported as g CO $2 / \mathrm{m}^{-2} / \mathrm{yr}^{-1}$; Conversion factor for $\mathrm{gC}$ to $\mathrm{CO} 2 \mathrm{e}=3.67$.

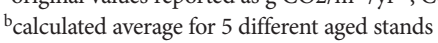

cecosystem respiration measured

proportion of respiratory tissue relative to photosynthesizing tissue increases as trees increase in size, which contributes to increasing the amount of $\mathrm{CO}_{2}$ emitted over time. These findings suggest that more frequent harvesting of relatively young trees creates stands that maintain a relatively low proportion of respiring tissue. However, this explanation, which is based on hypotheses outlined by the authors mentioned above, must be used with caution. As pointed out by Carey et al. (2001), other studies have indicated that stem respiration rate decreases with increase in tree size because the amount of $\mathrm{CO}_{2}$ respired per unit sapwood apparently decreases with age. If the observation of Carey et al. (2001) is correct, it is possible that CBM overestimates the amount of $\mathrm{CO}_{2}$ emitted for long rotations.

\section{Conclusion}

CBM provides a relatively user-friendly modelling environment to explore questions of FMP. Defaults provided within the model, supplemented by regional and/or stand-specific information, allow users to generate results that can be part of the context of their decision-making. Yield curves drive many of the pools and transfers and their accuracy and applicability are critical to good model output. As with all models, users must be aware of the assumptions (e.g., decay/transfer rates, $\mathrm{C}$ allocation) and limitations (spatial uniformity, difficulty dealing with succession) imposed as part of the process. In our study, we confirmed the importance and influence of the yield curves as well as the necessity to consider a variety of output variables.

After review of the results from this case study, it is appropriate to ask when is it sufficient to use the more empirically based modelling approach of CBM-CFS3 and when is it appropriate to choose a more complicated, process-based modelling approach? The latter generally requires more calibration data and users may be reluctant or unable to invest the time and resources required to locate such information. On the other hand, the relative simplicity of empirical modelling often means that default values that may not appropriately represent the system in question have to be accepted. The question of which type of model to use may lie at the heart of why people tend to avoid employing carbon budget modeling as a routine part of their management planning process. At this point, we recommend further independent investigation of the CBM-CFS3, as is the generally accepted practise with any science-based model. Once a sufficient number of critical reviews, case studies and/or assessments have taken place successfully, analysts and planners can confidently use the model.

Perhaps more importantly, we urge those responsible for FMP to consider the contribution that multiple models can 
make to the process (Larocque et al. 2011). In his keynote address to the 2009 Annual General Meeting of the International Society for Ecological Modeling, Alexey Voinov (Johns Hopkins University, USA) argued that "one model cannot be sufficient to represent all the details needed for decision-making and planning". Voinov argued for "integrated models" but not "integrated modelling". The latter approach suggests that somehow, someone can develop an accurate, reliable model that can contend with all of the variables of interest to every possible user (processes, stocks, inputs) and produce useful output. The "integrated models" approach argues that we already have many excellent, tested models that do a few things well and that our goal should be to find ways to integrate output from these various models. Examples of the integrated model approach can be found in the USA (Chesapeake Bay Program modeling suite; www.chesapeakebay.net) and in Europe (SEAMLESS - System for Environmental and Agricultural Modeling: Linking European Science and Society; www.seamless-ip.org). Model-linking software does exist so we need not start from scratch. For example, in the United States, the EPA has developed FRAMES, (Framework for Risk Analysis in Multi-media Environmental Systems) and in Europe, a consortium of European universities and private companies has developed OpenMI (Open Modeling Interface and Environment). For FMP, we might use a climate change model to predict future forest conditions, a gap model to predict successional patterns, a carbon model to predict production and allocation (essentially generate yield curves), a habitat model to assess species viability and an optimization model (such as SFMM) to generate resource use options. This approach will require collaboration by individuals and organizations who best know how to manage these models-scientists, government, and industry. Other benefits of collaboration on the modeling will be a) the necessity to explain and document underlying assumptions to people outside each discipline and $b$ ) the development of a joint understanding of the questions and issues from each perspective.

\section{Acknowledgements}

The authors gratefully acknowledge financial assistance from the Forestry Futures Trust Fund (Ontario) - Enhanced Forest Science Program. Technical assistance from the Carbon Accounting Team of the Canadian Forest Service, specifically W. Kurz, S. Kull, J. Metsaranta and G. Rampley, was invaluable. The authors express their appreciation to Abitibi Bowater Inc. for providing raw data from the Dog River Matawin Sustainable Forest License and to A. Innerd for undertaking the computer simulations. Finally, we wish to thank the anonymous reviewer(s) for their helpful comments.

\section{References}

Alemdag, I.S. 1982. Above-ground dry-matter of jack pine, black spruce, white spruce and balsam fir trees at two localities in Ontario. For. Chron. 58: 26-30.

Alemdag, I.S. 1988. A ratio method for calculating stem volume to variable merchantable limits and associated taper equations. For. Chron. 64: 18-26.

Banfield, G. E., J. S. Bhatti, H. Jiang and M. J. Apps. 2002. Variability in regional scale estimates of carbon stocks in boreal forest ecosystems: results from West-Central Alberta. For. Ecol. Mgmt. 169: 15-27.
Bottcher, H., W.A. Kurz and A. Freibauer. 2008. Accounting of forest carbon sinks and sources under a future climate protocol - factoring out past disturbance and management effects on age-class structure. Env. Sci. Poli. 11: 669-686.

Boudewyn, P., X. Song, S. Magnussen and M.D. Gillis. 2007. Model-based, Volume-to-Biomass Conversion for Forested and Vegetated Land in Canada. Canadian Forest Service, Victoria, BC. Inf. Rep. BC-X-411.

Buchmann, N. 2000. Biotic and abiotic factors controlling soil respiration rates in Picea abies stands. Soil. Biol. Biochem. 32: $1625-1635$.

Carey, E.V., A. Sala, R. Keane and R.M. Callaway. 2001. Are old forests underestimated as global carbon sinks? Global Change Biology 7: 339-344.

Chapin, F.S. et al. 2006. Reconciling carbon-cycle concepts, terminology, and methods. Ecosystems 9: 1041-1050.

Colombo, S.J., W.C. Parker, N. Luckai, Q. Dang and T. Cai. 2005. The effects of forest management on carbon storage in Ontario's forests. Ontario Forest Research Institute, Ministry of Natural Resources, Climate Change Research Report CCRR-03. 127 p.

Covington, A.D. 1981. Changes in forest floor organic-matter and nutrient content following clear cutting in northern hardwoods. Ecology 62: 41-48.

Diaz-Balteiro, L., M. Bertomeu and M. Bertomeu. 2009. Optimal harvest scheduling in Eucalyptus plantations. A case study in Galicia (Spain). For. Pol. Econ. 11: 548-554.

Gaumont-Guay, D., T.A. Black, H. McCaughey, A.G. Barrs, P. Krishnan, R. Jassal and Z. Nesic. 2009. Soil CO2 efflux in contrasting boreal deciduous and coniferous stands and its contribution to the ecosystem carbon balance. Global Change Biology. 15: $1302-$ 1319.

Golden, D.M., M.A. Smith and S.J. Colombo. 2011. Forest carbon management and carbon trading: A review of Canadian forest options for climate change mitigation. For. Chron. 87: 625-635.

Gower, S.T., R.E. McMurtrie and D. Murty. 1996. Aboveground net primary production decline with stand age: Potential causes. Trends Ecol. Evol. 11: 378-382.

Hanson, P.J., N.T. Edwards, C.T. Garten Jr. and J.R. Andrews. 2000. Separating root and soil microbial contributions to soil respiration: a review of methods and observations. Biogeochemistry 48: 115-146.

Heath, L.S., R.A. Birdsey and D.W. Williams. 2002. Methodology for estimating soil carbon for the forest carbon budget model of the United States, 2001. Envir. Poll. 116: 373-380.

Howard, E.A., S.T. Gower, J.A. Foley and C.J. Kucharik. 2004. Effects of logging on carbon dynamics of a jack pine forest in Saskatchewan, Canada. Global Change Biology. 10: 1267-1284.

Hughes, J.W. and T.J. Fahey. 1994. Litterfall dynamics and ecosystem recovery during forest development. For. Ecol. Manag. 63: 18198.

Hyvönen, R. et al. 2007. The likely impact of elevated [CO2], nitrogen deposition, increased temperature and management on carbon sequestration in temperate and boreal forest ecosystems: a literature review. New Phytologist 173:463-480.

Jandl, R., L. Vesterdal, M. Olsson, O. Bens, F. Badeck and J. Rock. 2007. Carbon sequestration and forest management. CAB Reviews: Perspectives in Agriculture, Veterinary Science, Nutrition and Natural Resources 2007 2, No. 017. 16p. Available at http://cabiblog.typepad.com/hand_picked/files/PAV2017.pdf.

Kull, S.J., W.A. Kurz, G.J. Rampley, G.E. Banfield, R.K. Schivatcheva and M.J. Apps. 2007. Operation-Scale Carbon Budget Model of the Canadian Forest Sector (CBM-CFS3) Version 1.0: User's Guide. Natural Resources Canada, Canadian Forestry Service, Northern Forestry Centre, Edmonton, AB.

Kurz, W.A. and M.J. Apps. 1999. A 70-Year Retrospective Analysis of Carbon Fluxes in the Canadian Forest Sector. Ecol. Appl. 9(2): 526-547. 
Kurz, W.A., M. Apps, E. Banfield and G. Stinson. 2002. Forest carbon accounting at the operational scale. For. Chron. 78(5): 672-679. Kurz, W.A., M.J. Apps, T.M. Webb and P.J. McNamee. 1992. Carbon Budget of the Canadian Forest Sector Phase I. Forestry Canada, Northern Forestry Centre, Edmonton, AB. Inf. Rep. NOR-X-326.

Kurz, W.A., S.J. Beukema and M.J. Apps. 1996. Estimation of root biomass and dynamics for the carbon budget model of the Canadian forest sector. Can. J. For. Res. 26: 1973-1979.

Kurz, W.A., S.J. Beukema and M.J. Apps. 1998. Carbon budget implications of the transition from natural to managed disturbance regimes in forest ecosystems. Mitigation and Adaptation Strategies for Global Change 2: 405-421.

Kurz, W.A., G. Stinson and G.J. Rampley. 2008a. Could increased boreal forest ecosystem productivity offset carbon losses from increased disturbances? Phil. Trans. Royal Soc. London. Series B, Biol. Sci. 363: 1501, 2261-2269.

Kurz, W.A., G. Stinson, G.J. Rampley, G.C. Dymond and E.T. Neilson. 2008b. Risk of natural disturbances makes future contribution of Canada's forests to the global carbon cycle highly uncertain. Proc. Natl. Acad. Sciences USA. 105 (5): 1551-1555.

Kurz, W.A. et al. 2009. CBM-CFS3: A model of carbon-dynamics in forestry and land-use change implementing IPCC standards. Ecol. Model. 220: 480-504.

Larocque, G.R., L. Archambault and C. Delisle. 2006. Modelling forest succession in two southeastern Canadian mixedwood ecosystem types using the ZELIG model. Ecol. Model. 199: 350-362.

Larocque, G.R., J.S. Bhatti, J.C. Ascough II, J. Liu, N. Luckai, D. Mailly, L. Archambault and A.M. Gordon. 2011. An analytical framework to assist decision makers in the use of forest ecosystem model predictions. Envir. Model. Software. 26(3): 280-288.

Lavigne , M.B., R. Boutin, R.J. Foster, G. Goodine, P.Y. Bernier and G. Robitaille. 2003. Soil respiration responses to temperature are controlled more by roots than by decomposition in balsam fir ecosystems. Can. J. For. Res. 33: 1744 - 1753.

Law, B.E., M. Williams, P.M. Anthoni, D.D. Baldochhi and M.H. Unsworth. 2000. Measuring and modelling seasonal variation of carbon dioxide and water vapour exchange of Pinus ponderosa forest subject to soil water deficit. Global Change Biology 6: 613-630.

Lee, J., I.K. Morrison, J.-D. Leblanc, M.T. Dumas and D.A. Cameron. 2002. Carbon sequestration in trees and regrowth vegetation as affected by clearcut and partial cut harvesting in a secondgrowth boreal mixedwood. For. Ecol. Mgmt. 169: 83-101.

Li, Z., M.J. Apps, E. Banfield and W.A. Kurz. 2002. Estimating net primary production of forests in the Canadian Prairie Provinces using an inventory-based carbon budget model. Can. J. For. Res. 32: 161-169.

Liski, J., D. Perruchoud and T. Karjalainen. 2002. Increasing carbon stocks in the forest soils of western Europe. For. Ecol. Mgmt. 169: 159-175.

Liu, J., C. Peng, M. Apps, Q. Dang, E. Banfield and W.A. Kurz. 2002. Historic carbon budgets of Ontario's forest ecosystems. For. Ecol. Mgmt. 169: 103-114.

Martin, J.L., S.T. Gower, J. Plaut and B. Holmes. 2005. Carbon pools in a boreal mixedwood logging chronosequence. Global Change Biology 11: 1883-1894.

McCaughey, J.H., M.R. Pejam, M.A. Arain and D.A. Cameron. 2006. Carbon dioxide and energy fluxes from a boreal mixedwood forest ecosystem in Ontario, Canada. Agric. For. Meteor. 140: 79-96. Meentemeyer, V. 1978. Macroclimate and lignin control of litter decomposition rates. Ecology. 59(3): 465-472.
Moorhead, D.L., W.S. Currie, E.B. Rastetter, W.J. Parton and M.E. Harmon. 1999. Climate and litter quality controls on decomposition: an analysis of modeling approaches. Global Biogeochem Cycles 13:575-89.

[OMNR] Ontario Ministry of Natural Resources. June 2004. Forest Management Planning Manual for Ontario's Crown Forests. Queen's Printer for Ontario, Toronto, ON. 440 p.

Penner, M., M. Woods, J. Parton and A. Stinson. 2008. Validation of empirical yield curves for natural-origin stands in boreal Ontario. For. Chron. 84: 704-717.

Perala, D.A., 1990. Quaking aspen. In R.M. Burns and B.H. Honkala (Tech. Coords.). Silvics of North America. II. Hardwoods. Agriculture Handbook, vol. 654, USDA Forest Service, Washington, DC.

Price, D.T., D.H. Halliwell, M.J. Apps, W.A. Kurz and S.R. Curry. 1997. Comprehensive assessment of carbon stocks and fluxes in a Boreal-Cordilleran forest management unit. Can. J. For. Res. 27: 2005-2016.

Rudolf, T.D. and P.R. Laidly. 1990. Jack pine. In R.M. Burns and B.H. Honkala (Tech. Coords.). Silvics of North America. I. Conifers. Agriculture Handbook, vol. 654, USDA Forest Service, Washington, DC.

Russel, C.A. and R.P. Voroney. 1998. Carbon dioxide efflux from the floor of a boreal aspen forest. i. Relationship to environmental variable and estimates of C respired. Can. J. Soil Sci. 78: 2, 301-310. Ryan, M.G., D. Binkley and J.H. Fownes. 1997. Age-related decline in forest productivity: pattern and process. Adv. Ecol. Res. 27: 213-262.

Schulze, E.-D., C. Wirth and M. Heimann. 2000. Managing forests after Kyoto. Science 22: 2058-2059.

Shaw, C.H., J.S. Bhatti and K.J. Sabourin. 2005. An Ecosystem Carbon Database for Canadian Forests. Natural Resources Canada, Canadian Forest Service, Northern Forestry Centre, Edmonton, AB. Inf. Rep. NOR-X-403.

Siltanen, R.M., M.J. Apps. S.C. Zoltai, R.M. Mair and W.L. Strong. 1997. A soil profile and organic carbon data base for Canadian forest and tundra mineral soils. Nat. Resour. Can., Can. For. Serv., North. For. Cent. Edmonton, AB. 50 p.

Streigl, R.G. and K.P. Wickland. 1998. Effects of clearcut harvest on soil respiration in a jack pine-lichen woodland. Can. J. For. Res. 28: 534-539.

Ter-Mikaelian, M.T., S.J. Colombo and J.X. Chen. 2008. Fact and fantasy about forest carbon. For. Chron. 84: 166-171.

Tupek, B., K. Minkkinen, P. Kolari, M. Starr, T. Chan, J. Alm, T. Vesala, J. Laine and E. Nikinmaa. 2008. Forest floor versus ecosystem $\mathrm{CO}_{2}$ exchange along boreal ecotone between upland forest and lowland mire. Tellus. 60B: 153-166.

Uchida, M., T. Nakatsubo, T. Horikoshi and K. Nakane. 1998. Contribution of micro-organisms to the carbon dynamics in black spruce (Picea mariana) forest soil in Canada. Ecol. Research. 13: $17-26$.

Van Wagner, C.E. 1978. Age-class distribution and the forest fire cycle. For. Chron. 8: 220-227.

Vogel, J.G., D.W. Valentine and R.W. Ruess. 2005. Soil and root respiration in mature Alaskan black spruce forests that vary in soil organic matter decomposition rates. Can. J. For. Res. 35: 161 - 174. Yanai, R.D., W.S. Currie and C.L. Goodale. 2003. Soil carbon dynamics after forest harvest: an ecosystem paradigm reconsidered. Ecosystems. 6: 197-212. 